\title{
DID DARWIN HAVE SYNCOPE CAUSED BY CHAGAS' DISEASE?
}

\section{TO THE EDITOR}

The year 2009 is the $150^{\text {th }}$ Anniversary of the publication of On the Origin of Species (24 November 1859) and the $200^{\text {th }}$ Anniversary of Darwin's birth. Charles Robert Darwin was born on February 12, 1809 in Shrewsbury, England. From 1831 to 1836, Darwin served as naturalist aboard the H.M.S. Beagle on a British science expedition around the world.' In South America, Darwin found fossils of extinct animals that were similar to modern species. On the Galapagos Islands in the Pacific Ocean he noticed many variations among plants and animals of the same general type as those in South America. The expedition visited places around the world, and Darwin studied plants and animals everywhere he went, collecting specimens for further study. Out of this tudy, Darwin formulated several theories. He set forth these theories in his book called, On the Origin of Species by Means of Natural Selection, or the Preservation of Favoured Races in the Struggle for Life (1859) or "The Origin of Species" for short.' After publication of Origin of Species, Darwin continued to write on botany, geology, and zoology until his death in 1882 . He is buried in Westminster Abbey. In 1832, Darwin arrived in Brazil, where he stayed for four months, particularly in Rio de Janeiro and Salvador/Bahia. Later, The Origin of Species, called the attention of a German descendant physician, Fritz Mueller, a naturalist, who lived in Blumenau and Florianopolis, Santa Catarina. There he studied Crustacea species and his studies resulted in a supporting book to Darwin's theories entitled "Für Darwin", later translated in English as "Facts and Arguments for Darwin". He and Darwin kept correspondence until Darwin's death in 1882.,2

Several historical studies and biographical essays have tried to correlate his illnes during his lifetime, described by himself, with several possible diseases. Among them, anxiety, panic disorder with agoraphobia, hypocondria, arsenic poisoning, chronic allergy, Crohn's disease, lactose intolerance and Chagas' disease have been postulated. ${ }^{3,4}$ The hypothesis of Chagas' disease is quite exciting and is based on two points. First, Darwin mentioned in his autobiography that he was bitten by several Benchucas, a insect species Reduvius, a great black bud of the Pampas, on March 25, 1835, in the small village Luján, Mendon- za province, Argentina. ${ }^{5}$ There is a general consensus that Benchucas were in fact Triatoma infestans, the insect carrier of Trypanosoma cruzi, described by the Brazilian scientist Carlos Chagas, in 1909. ${ }^{5,6} \mathrm{~A}$ second supporting factor is the set of symptoms refered by Darwin himself, during his chronic illness, including digestive complaints (vomiting attacks, eructation, flatulence) and particularly the pre-syncopal and syncopal episodes, more frequent at the end of his life, associated with complaints of effort dyspnea and palpitations, in keeping with a cardiomyopathy leading to cardiac syncopal episodes (described as occurring in supine position). ${ }^{1.7}$ Nevertheless, the possibility of Chagas' disease acquired by Darwin during his passage in South America is still discussed, as well as even nowadays his genial theory of evolution, in special among some groups of religious theorists.

Acknowledgments - We are grateful to Prof. Francisco Javier Carod-Artal, from The Sarah Network of Rehabilitation Hospitals, Sarah Hospital, Brasilia, DF, Brazil, for his helpful comments.

\section{REFERENCES}

1. Desmond A, Moore J. Darwin. A vida de um evolucionista atormentado. $3^{a}$ edição. São Paulo: Geração Editorial, 2000.

2. Müller F. Facts and arguments for Darwin. Charleston: BiblioBazaar, 2007.

3. Campbell AK, Matthews SB. Darwin's illness revealed. Postgrad Med J 2005;81:248-251.

4. Orrego F, Quintana C. Darwin's illness: a final diagnosis. Notes Rec R Soc Lond 2007;61:23-29.

5. Adler S. Darwin's illness. Br Med J 1965;1:1249-1250.

6. Woodruff AW. Darwin's health in relation to his voyage to South America. Br Med J 1965;1:745-750.

7. Darwin F. The life and letters of Charles Darwin, including an autobiographical chapter. London: Murray, 1887.

Hélio A.G. Teive, MD, PhD

Walter O. Arruda, MD, MsC

Neurology Service / Internal Medicine Department

Hospital de Clínicas / Federal University of Paraná

E-mail: hagteive@mps.com.br

CORRESPONDÊNCIA. Esta seção de Arquivos de Neuro-Psiquiatria divulga opiniões e observações construtivas acerca de artigos publicados em seus últimos números. São aceitas cartas assinadas, sucintas e desprovidas de caráter pessoal, abordando aspectos objetivos dos artigos e utilizando até cinco referências bibliográficas. Enviar sua contribuição em uma via acompanhada do respectivo disquete. Utilizar o endereço: Arquivos de Neuro-Psiquiatria, Praça Amadeu Amaral 47 / 33, 01327-010 São Paulo SP ou E-mail: arq.neuropsiquiatria@terra.com.br 